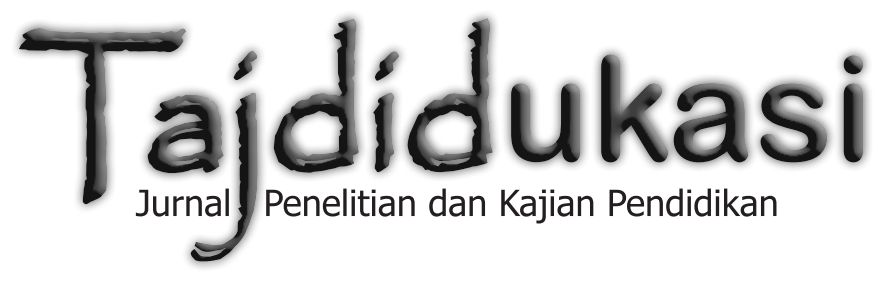




\section{Tajdidukasi}

Volume VIII, No. 1, Januari 2018

ISSN: 1979-6943

Tajdidukasi: Jurnal Penelitian dan Kajian Pendidikan merupakan jurnal Penelitian dan Kajian Pendidikan yang berisi Penelitian Tindakan Kelas (PTK) dan Penelitian Tindakan Sekolah (PTS) serta Kajian Pendidikan interdisipliner di Perguruan Tinggi yang diterbitkan Majelis Pendidikan Dasar dan Menengah Pimpinan Wilayah Muhammadiyah Daerah Istimewa Yogyakarta. Artikel hasil PTK dan PTS serta kajian pemikiran pendidikan ditulis oleh para Guru dan Kepala Sekolah serta Dosen dalam mengujicobakan metode dan strategi pembelajaran untuk meningkatkan kualitas pendidikan baik SD/MI, SMP/MTs dan SMA/MA/SMK serta Perguruan Tinggi. Artikel PTK dan PTS fokus pada mata pelajaran di sekolah/madrasah, seperti Ilmu Pengetahuan Alam (IPA), Imu Pengetahuan Sosial (IPS), Matematika, Fisika, Kimia, bahkan teknik, seperti Teknik Mesin, Elektro, Informatika dan lain sebagainya. Sementara itu, artikel Kajian Pendidikan merupakan penelitian interdisipliner dan multidisipliner yang dilakukan Dosen di Perguruan Tinggi terhadap khasanah keIslaman.

Tajdidukasi: Jurnal Penelitian dan Kajian Pendidikan adalah jurnal terbuka yang versi softfile-nya bisa dibaca dan diakses secara gratis, sementara versi print out/ hardcopy dapat diperoleh dengan menghubungi distributor di alamat serial tajdidukasi.ac.id. Sof-file keseluruhan artikel yang diterbitkan dapat diakses melalui Tajdidukasi Open Access Juornal di www.dikdasmenpwmdiy.or.id

\section{Pimpinan Editor \\ Suyadi, Universitas Ahmad Dahlan (UAD) Yogyakarta, Indonesia}

\section{Anggota Editor}

Arif Budi Raharjo, Universitas Muhammadiyah Yogyakarta (UMY), Indonesia

Achmad Muhammad, UIN Sunan Kalijaga Yogyakarta, Indonesia

Hendro Widodo, Universitas Ahmad Dahlan (UAD) Yogyakarta

Mundzirin Yusuf, UIN Sunan Kalijaga Yogyakarta, Indonesia

Sumedi, UIN Sunan Kalijaga Yogyakarta, Indonesia

Sukamto, Universitas Muhammadiyah Yogyakarta (UMY), Indonesia

Sumarsono, UIN Sunan Kalijaga Yogyakarta Indonesia

Sarjilah (Lembaga Penjaminan Mutu Pendidikan) Yogyakarta

Fathur Rahman, M.Si., Universitas Negeri Yogyakarta (UNY) Indonesia

\section{Editor Pelaksana}

Suryanto, Universitas Muhammadiyah Yogyakarta (UMY), Indonesia

Suyatno, Universitas Ahmad Dahlan (UAD) Yogyakarta

Farid Setiawan, Universitas Ahmad Dahlan (UAD) Yogyakarta

Alamat Redaksi:

Kantor Majelis Pendidikan Dasar dan Menengah Pimpinan

Wilayah Muhammadiyah D.I. Yogyakarta

Jl. Gedongkuning No. 130B Yogyakarta

Kode Pos : 55171

Telephone : (0274) 377078

Facsimile : (0274) 371718

Website : www.dikdasmenpwmdiy.or.id

E-Mail : tajdidukasi@dikdasmenpwmdiy.or.id 


\title{
PENGGUNAAN METODE EKSPERIMEN UNTUK MENINGKATKAN PRESTASI BELAJAR IPA SISWA SMP MUHAMMADIYAH 2 BAMBANGLIPURO
}

\author{
Nastitik \\ SMP Muhammadiyah 2 Bambanglipuro \\ Email: Nastitikbunda@gmail.com
}

\begin{abstract}
Abstrak
Penelitan ini bertujuan untuk mengetahui peningkatan prestasi belajar IPA melalui metode eksperimen pada siswa kelas VIII SMP Muhammadiyah 2 Bambanglipuro.Penelitian ini merupakan Penelitian Tindakan kelas yang bersifat kolaboratif, Disain penelitian yang dipergunakan dalam penelitian tindakan ini adalah model kemmis yang dikembangkan oleh Stephen Kemmis dan Robbin Mc. Taggart yang dalam pelaksanaannya terdiri dari 2 siklus, masing-masing siklus terdiri dari 2 kali pertemuan.Pada tiap tiap siklus meliputi tahap perencaaan,tindakan,observasi dan refleksi. Metode penelitian ini menggunakan analisa deskriptif kualitatif untuk keaktifan siswa sedangkan data ketuntasan dan prestasi siswa dengan deskriptif kuantitatif.Berasarkan hasil penelitian ,penggunaan metode eksperimen dapat meningkatkan pestasi belajar IPA ,hal ini dibuktikan dengan peningkatan keaktifan siswa dari $53.12 \%$ pada siklus 1 meningkat menjadi $71.89 \%$ pada siklus 2, nilai Ketuntasan klasikal dari 56\% pada siklus 1 menjadi $75 \%$ pada siklus 2,nilai rata-rata individual dari 61.25 pada siklus1 menjadi 69 pada siklus 2. Berdasar hasil penelitian disarankan bagi guru hendaknya menerapkan metode eksperimen agar siswa dapat belajar dengan aktif serta prestasi belajarnya dapat meningkat.
\end{abstract}

Kata kunci: Metode eksperimen, prestasi belajar, IPA

\section{A. PENDAhULUAN}

Pendidikan merupakan proses tanpa akhir yang diupayakan oleh siapa pun, terutama (sebagai tanggung jawab) negara. Sebagai upaya untuk meningkatkan kesadaran dan ilmu pengetahuan, pengetahuan telah ada seiring dengan lahirnya peradaban manusia. R.S. Peters dalam bukunya The Philosophy of Education menandaskan bahwa pada hakikatnya pendidikan tidak mengenal akhir karena kualitas kehidupan manusia terus meningkat (Nurani Soyomukti, 2010: 29).
Pendidikan sebagai proses mengubah tingkah laku anak didik agar menjadi manusia dewasa yang mampu hidup mandiri dan sebagai anggota masyarakat dalam lingkungan alam sekitar dimana individu itu berada, dan dengan kata lain pada dasarnya pendidikan merupakan usaha manusia (pendidik) untuk dengan penuh tanggung jawabnya membimbing anak-anak didik menjadi kedewasaan (Syaiful Syagala, 2010: 3-4).

Dari maknanya yang sempit pendi- 
dikan identik dengan sekolah. Berkaitan dengan hal ini, pendidikan adalah pengajaran yang diselenggarakan di sekolah sebagai lembaga tempat mendidik (mengajar). Pendidikan merupakan segala pengaruh yang diupayakan sekolah terhadap anak dan remaja (usia sekolah) yang diserahkan kepadanya (sekolah) agar mempunyai kemampuan kognitif dan kesiapan mental yang sempurna berkesadaran maju yang berguna bagi mereka untuk terjun ke masyarakat sebagai individu maupun makhluk sosial (Nurani Soyomukti, 2010: 40).

Pembelajaran IPA pada situasi sekarang ini perlu menyesuaikan dengan kondisi di lingkungan siswa. Untuk mengembangkan potensi diperlukan adanya kerjasama dari guru dan murid dalam proses pembelajaran. Guru merupakan sosok pendidik dan pengajar yang menyentuh kehidupan pribadi siswa, oleh siswa sering kali dijadikan tokoh teladan, bahkan menjadi tokoh identifikasi diri. Jika guru mampu menjadi sumber inspirasi dan motivasi bagi anak didiknya, maka hal itu akan menjadi kekuatan anak didik dalam mengejar cita-cita besarnya di masa depan. Oleh karena itu, kehadiran guru dalam proses pembelajaran memegang peranan yang sangat penting, belum dapat digantikan oleh mesin, radio, tape recorder ataupun komputer yang paling modern sekalipun. Dalam proses pembelajaran, guru hendaknya memiliki strategi agar siswa dapat belajar secara efektif dan efisien, mengena pada tujuan yang diharapkan. Metode pembelajaran satu arah tentu kurang relevan dengan situasi yang ada pada saat ini. Pendekatan yang sesuai adalah pendekatan pembelajaran yang mencakup kesesuaian antara situasi belajar anak dengan situasi kehidupan nyata di masyarakat.

Pembelajaran dikatakan baik, apabila siswa belajar dengan pengalaman langsung, di mana siswa ikut berartisipasi aktif dalam kegiatan pembelajaran, serta siswa mendapatkan sebuah pengalaman dari proses pembelajaran tersebut salah satunya berupa prestasi belajar yang baik. Hal tersebut sejalan dengan teori yang dikemukakan oleh Jean Peaget bahwa tahap perkembangan anak usia SMP (usia 13-15 tahun) pada umumnya mereka berpikir atas dasar pengalaman konkret/ nyata (Hendro Darmojo dan Jenny R. E Kligis, 1992: 19).

Siswa akan mendapatkan prestasi yang baik, jika selama proses pembelajaran dapat memahami materi dengan baik. Keberhasilan memahami materi sangat dipengaruhi oleh metode pembelajaran yang digunakan guru. Ketika siswa ikut berpartisipasi aktif, baik itu aktif mental, aktif fisik, maupun aktif sosial, kesempatan untuk memahami materi akan semakin besar bagi siswa. Keberhasilan juga dapat diperoleh dari proses pembelajaran, jika proses pembelajaran tersebut sesuai dengan tujuan pembelajaran yang telah ditentukan. Artinya segala aktivitas guru dan siswa selama pembelajaran tetap berorientasi pada tujuan pembelajaran.

Salah satu tugas guru professional adalah mampu membantu dan mendo- 
rong peserta didik agar potensi mereka dapat tumbuh dan berkembang secara optimal.Oleh karena itu dalam proses pembelajaran sains, guru harus terus berupaya dengan berbagai metode dan strategi agar peserta didik dapat menguasai kompetensi serta pemahaman konsep dan penerapannya sebagaimana yang diamanatkan dalam kurikulum. Kurikulum 2013 dirancang untuk memperkuat kompetensi peserta didik dari sisi pengetahuan, ketrampilan dan sikap secara utuh.

Modul (PKB,2017:21), ada banyak jenis metode pembelajaran yang dapat digunakan dalam proses pembelajaran. Pada umumnya metode tersebut dapat digunakan pada semua mata pelajaran, tetapi ada metode tertentu yang hanya digunakan pada mata pelajaran tertentu. masing-masing metode umumnya tidak dapat berdiri sendiri, artinya dalam suatu proses pembelajaran guru dapat menggunakan lebih dari satu metode pembelajaran.

Berdasarkan hasil observasi kepada beberapa guru di SMP Muhammadiyah 2 Bambanglipuro, pembelajaran IPA yang berlangsung di kelas pada umumnya guru menggunakan metode ceramah yang berpusat pada guru. Siswa masih mendengarkan materi dan mencatat hal-hal yang penting dari materi. Untuk pemahaman sesekali guru menggunakan metode diskusi, namun merasa kesulitan dalam membagi kelompok dan mengingat waktu, serta target pengajaran materi yang ada. Biasanya dalam diskusi hanya siswa yang aktif satu atau dua anak saja, sedangkan yang lain sibuk sendiri atau bermainmain dengan teman yang lain. Selain itu pembelajaran yang dikembangkan bersifat tekstual dengan buku sebagai sumber pembelajaran yang utama dan kurang optimalnya penggunaan sumber belajar maupun media pembelajaran.

Hal ini menunjukan bahwa guru belum menggunakan metode pembelajaran yang bervariasi dan sesuai dengan materi yang dipelajari serta yang mengutamakan pengalaman langsung pada siswa, sehingga pemahaman pada materi menjadi kurang dan prestasi belajar siswa rendah. Hal tersebut dapat terlihat dari nilai UTS mata pelajar IPA yang diperoleh siswa pada semester satu masih di bawah KKM. Metode mempunyai andil yang cukup besar dalam proses pembelajaran. Kemampuan yang diharapkan dapat dimiliki siswa, akan ditentukan oleh kerelevansian penggunaan suatu metode yang sesuai dengan tujuan pembelajaran. Salah satu metode yang dapat dikembangkan agar siswa aktif dalam pembelajaran yaitu metode eksperimen. Metode eksperimen merupakan metode mengajar yang dalam penyajian atau pembahasan materinya melalui percobaan atau mencobakan sesuatu mengamati secara proses. Pengalaman yang dialami secara langsung dapat tertanam dalam ingatannya. Dengan keterlibatan fisik, mental dan emosional siswa dalam metode ini diharapkan dapat menumbuhkan rasa percaya diri dan perilaku siswa yang inovatif dan kreatif. 
Metode eksperimen merupakan metode yang biasanya diterapkan dalam pembelajaran IPA. Pembelajaran IPA dengan menggunakan metode eksperimen akan lebih efektif karena disertai dengan percobaan-percobaan untuk menemukan bukti kebenaran dari teori sesuatu yang sedang dipelajarinya. Menurut Moedjiono dan Moh Dimyati (1993: 77), metode eksperimen patut diterapkan di sekolah sejak dini . Jika siswa hanya diberi teori tanpa adanya praktek untuk membuktikan kebenaran teori tersebut, siswa akan mengalami kesulitan dalam mencerna inti pembelajaran. Pengalaman langsung melalui percobaan-percobaan akan membuat siswa mengerti dan memahami materi yang sedang dipelajari serta membuat pembelajaran yang bermakna karena mereka mengalami sendiri prosesproses tersebut.

Proses pembelajaran di sekolah mengacu pada Permendiknas RI N0 41 tahun 2007 tentang standar proses. Kegiatan pembelajaran pada peraturan tersebut terdiri dari pendahuluan, inti dan penutup.Pendahuluan merupakan tindakan awal pertemuan untuk membangkitkan motivasi dan memfokuskan para siswa untuk berperan aktif dalam proses belajar mengajar. Kegiatan inti merupakan prosespembelajaran untuk mencapai kompetensi dasar, yang dilakukan secar interaktif, menyenangkan,menantang untuk berpartisipasi aktif serta memberikan ruang yang cukup bagi kreativitas dan kemandirian sesuai dengan minat dan bakat dan perkembangan fisik serta psikologis peserta didik.Penutup kegiatan yang dilakukan untuk mengakhiri aktifitas pembelajaran yang dapat dilakukan dalam bentuk rangkuman atau kesimpulan, penilaian dan refleksi, umpan balik dan tidak lanjut.Proses pembelajaran yang sudah ditetapkan dalam peraturan ini sudah sangat ideal untuk diaplikasikan di dalam kelas.

Manfaat penggunaan metode eksperimen dalam pembelajaran Ilmu Pengetahuan Alam adalah agar siswa mampu mencari dan menemukan sendiri berbagai jawaban atau persoalan-persoalan yang dihadapinya dengan mengadakan percobaan sendiri. Juga siswa dapat terlatih dalam cara berpikir yang ilmiah. Metode eksperimen menurut Djamarah (2002:95) adalah cara penyajian pelajaran, dimana siswa melakukan percobaan dengan mengalami sendiri sesuatu yang dipelajari. mengikuti suatu proses, mengamati suatu obyek, keadaan atau proses sesuatu. Metode eksperimen memberikan kesempatan kepada siswa secara perorangan atau kelompok untuk melakukan percobaan sehingga cermat, terampil dan aktif melakukan perencanaan, pengumpulan data, pengamatan, penemuan hingga menarik kesimpulan.

Prosedur eksperimen menurut Roestiyah (2001:81) adalah :

1) Perlu dijelaskan kepada siswa tentang tujuan eksperimen, mereka harus memahami masalah yang akan dibuktikan melalui eksperimen.

2) Memberi penjelasan kepada siswa tentang alat-alat serta bahan-bahan 
yang akan dipergunakan dalam eksperimen, hal-hal yang harus dikontrol dengan ketat, urutan eksperimen, hal-hal yang perlu dicatat.

3) Selama eksperimen berlangsung guru harus mengawasi pekerjaan siswa. Bila perlu memberi saran atau pertanyaan yang menunjang kesempurnaan jalannya eksperimen.

4) Setelah eksperimen selesai guru harus mengumpulkan hasil penelitian siswa, mendiskusikan di kelas, dan mengevaluasi dengan tes atau tanya jawab.

Keberhasilan kegiatan belajar sangat ditentukan oleh adanya suatu intensitas kesiapan mengajar. Dengan begitu guru dalam proses pembelajaran harus memiliki kemampuan tersendiri guna mencapai harapan yang dicita-citakan dalam melaksanakan pendidikan pada umumnya dan proses pembelajaran pada khususnya.

Rendahnya hasil belajar pada umumnya dalam pembelajaran tidak diikuti perilaku pembuktian maupun penemuan dari anak itu sendiri. Timbulnya kesalahan konsep terjadi karena adanya teori tanpa dipraktekkan dalam eksperimen. Oleh karena itu salah satu alternatif untuk meningkatkan prestasi belajar anak adalah dengan metode praktikum atau lebih dikenal dengan eksperimen. Menurut (Nuryani,R,2010:108),metode eksperimen adalah cara penyajian pelajaran dengan menggunakan percobaan. dengan melakukan eksperimen siswa melakukan kegiatan yang mencakup pengamatan dan penggunaan alat-alat
praktikum.Siswa dapat membuktikan sendiri konsep yang mereka terima, sehingga kemampuan anak anak meningkat baik pada aspek kognitif maupun aspek psikomotornya. Mata pelajaran IPA tidak bisa hanya dengan metode ceramah tanpa ada demonstrasi dan yang lebih mengena dengan pembuktian adalah eksperimen.

Hipotesis tindakan pada penelitian ini adalah "Penggunaan metode eksperimen,akan dpat meningkatkan prestasi belajar siswa kelas VIII SMP Muhammadiyah 2 Bambanglipuro tahun pelajaran 2017-2018.

Tujuan penelitian ini untuk mengetahui peningkatan prestasi belajar IPA,melalui metode eksperimen pada siswa kelas VIII SMP Muhammadiyah 2 Bambanglipuro.

\section{B. METODE PENELITIAN}

Disain penelitian yang dipergunakan dalam penelitian tindakan ini adalah model kemmis yang dikembangkan oleh Stephen Kemmis dan Robbin Mc. Taggart yang dikutip oleh Parjono dalam Panduan Penelitian Tindakan Kelas (2007:22), penelitian tindakan kelas ini dilaksanakan dalam beberapa siklus. Setiap siklusnya meliputi beberapa tahapan yang meliputi perencanaan (planning), tindakan (action), pengamatan (observation), dan refleksi (reflection) dalam suatu spiral yang saling terkait. Penelitian dilaksanakan di SMP Muhammadiyah 2 Bambanglipuro.Subjek penelitian adalah siswa Kelas VIII tahun 
pelajaran 2017/2018 sebanyak 16 siswa. Metode pengumpulan datanya menggunakan observasi, tes dan dokumentasi.

Data yang diperoleh dari keseluruhan tindakan selanjutnya dianalisis secara kualitatif maupun kuantitatif,dengan bantuan kolaborator dan lembar observasi ,hasil yang diperoleh dibandingkan antara siklus 1 dan 2,apabila antara siklus 1 dan 2 menunjukkan kenaikan berarti prestasi belajar maupun keaktifan meningkat. Indikator keberhasilan tindakan ini meliputi: (1).Aktivitas siswa ditandai dengan membaca sumber belajar, bertanya dan mengemukakan pendapat,mendengarkan teman saat presentasi, menulis hasil presentasi serta berani tampil di depan kelas.(2) penigkatan kemampuan siswa dalam penguasaan konsep IPA dengan menggunakan evaluasi pembelajaran dari aspek kognitif dengan skor KKM 65(ketuntasan belajar individual 65\%) dan klasikal $70 \%$ berdasar Kompetensi dasar yang telah ditentukan.Ketuntasan klasikal dan rata-rata berdasarkan nilai tes siswa meningkat dari siklus 1 ke siklus 2

Metode eksperimen memiliki beberapa keunggulan antara lain Membuat siswa lebih percaya atas kebenaran atau kesimpulan berdasarkan percobaanya, siswa tidak mudah lupa tentang hasil eksperimen, dapat menetapkan tujuan eksperimen, membina siswa untuk membuat terobosan-terobosan baru dengan penemuan dari hasil percobaanya dan bermanfaat bagi kehidupan manusia (Yamin, 2005:66). Metode eksperimen juga mengembangkan kemampuan berpikir dan bekerjasama. Pada tahapan berpikir, siswa bisa berpikir bersama tentang eksperimen dan menuliskan hasil eksperimen serta menjawab soal yang telah di sediakan, sedangkan tahapan bekerjasama siswa merangkai hingga menyimpulkan hasil eksperimen sacara bersama serta berdiskusi secara berkelompok.

\section{HASIL DAN PEMBAHASAN}

Hasil observasi guru sebelum penelitian ini dilaksanakan menunjukkan bahwa kemampuan belajar IPA pada kelas VIII masih rendah, hal ini bisa dibuktikan dengan nilai PAS yang masih di bawah KKM.

Selain itu pelajaran IPA termasuk materi yang sulit dipahami,hal ini dapat dilihat pada saat pembelajaran banyak siswa yang kurang berminat, respon siswa terhadap pertanyaan yang diajukan guru kurang baik.Siswa kurang aktif dalam mengikuti pelajaran.Disamping itu metode yang digunakan guru kurang menarik.Hal tersebut membuat kurangnya interaksi positif antar guru dan siawa.

Deskripsi pelaksanaan penelitian ini,diuraikan sebagai berikut:

\section{Siklus 1}

a. Perencanaan

Kegiatan yang dilakukan pada perencanaan siklus 1 adalah menyusun instrument penelitian, seperti menyusun Perangkat pembelajaran berupa RPP , menyiapkan materi pelajaran, membuat lembar kerja siswa ,menyiapkan alat dan bahan , membuat lembar observasi 
dan catatan lapangan untuk mengumpulkan data tentang aktivitas siswa selama pembelajaran siklus 1 , serta menyusun soal tes evaluasi akhir siklus.

b. Pelaksanaan

Tindakan yang dilakukan mengacu pada perencanaan tindakan yang telah dibuat.Siklus 1 dilaksanakan 2 kali pertemuan.Pertemuan pertama pada hari Rabu,31 Januari 2018 dan Kamis 1 Februari 2018.Berikut ini adalah langkahlangkah yang dilakukan pada siklus 1 .

1) Pertemuan pertama

Pertemuan pertama siklus 1 ini dilaksanaan pada jam ke 6-7, atau tepatnya pada pukul 11.00 - 12 20.Pertemuan pertama ini terbagi menjadi 3 langkah kegiatan yaitu kegiatan awal, kegiatan inti dan penutup. Kegiatan awal dimulai dengan berdoa dilanjutkan presensi kelas, kemudian guru menjelaskan tujuan pembelajaran .Adapun tujuan pertemuan ini adalah menjelaskan konsep tekanan, menganalisis hubungan antara gaya dan luas permukaan terhadap besarnya tekanan.Sebelum menyampaikan materi guru melakukan apresepsi .Dalam kegiatan ini guru membagi siswa dalam 4 kelompok, setelah siswa menempatkan diri dalam kelompoknya guru mempersilahkan tiap tiap kelompok untuk mengambil alat dan bahan percobaan.Guru membagikan LKS dan siswa mulai melakukan percobaan. Pembelajaran diakhiri dengan membuat kesimpulan,kemudian guru melakukan refleksi dengan menanyakan kesan siswa terhadap pembelajaran yang diikuti.
Guru memberi tugas dan menyampaikan materi berikutnya

Hasil dari pertemuan 1 masih banyak siswa yang belum menggunakan sumber belajar, belum memahami LKS sehingga jalannya percobaan tidak seperti yang diharapkan.Ada beberapa kelompok yang keliru dalam membaca neraca pegas,sehingga hasil pengukurannya kurang tepat.Diakhir percobaan sebagian besar siswa kemampuan menghitung kurang lancar, sehingga hasil penghitungan yang diperoleh masih banyak yang salah.Belum banyak kelompok yang mau mengajukan pertanyaan dan masih kelihatan kurang percaya diri saat presentasi.

2) Pertemuan 2

Pertemuan 2 dilaksanakan pada hari Kamis, 1 Februari 2018 jam 1-2 tepatnya pukul $07.00-08.20$ wib.Kegiatan ini diawali dengan berdoa, mengecek kehadiran siswa dan melakukan apresepsi.Guru kemudian menyampaikan tujuan pembelajaran,yaitu menganalisis tekanan zat cair pada kedalaman tertentu, menjelaskan penerapan tekanan hidrostatis dalam kehidupan seharihari dan menentukan faktor-faktor yang mempengaruhi tekanan hidrostatis. Selanjutnya siswa secara berkelompok melakukan eksperimen tentang pengaruh kedalaman terhadap besar kecilnya tekanan dalam zat cair.Semua kelompok mengambil alat dan bahan yang sudah disiapkan dan memulai merangkai alat sesuai petunjuk kerja maupun penjelasan guru .Setelah selesai melakukan 
percobaan salah satu kelompok mempresentasikan di depan kelas,sedang kelompok yang lain menanggapinya. Kegiatan diakhiri dengan membuat kesimpulan.Dimana besarnya tekanan hidrostatis dipengaruhi oleh kedalaman zat cair dan massa jenis zat cair.

Hasil dari pertemuan 2 siswa keliha$\tan$ lebih antusias dibanding pertemuan 1, hal ini bisa dilihat dari nilai keaktifannya yang meningkat.Kemampuan menghitung sedikit lebih meningkat di banding pertemuan 1, hal ini di lihat dari hasil pengamatan guru pada saat eksperimen berlangsung, disamping itu sebagian besar kelompok sudah lebih teliti dan hati hati dalam melakukan percobaan,hanya 1 kelompok yang masih kelihatan ceroboh.

c. Hasil Pengamatan

1) Aktivitas belajar Siswa

Observasi dilaksanakan selama proses pembelajaran dan di bantu oleh seorang observer yang mengamati aktivitas belajar siswa sesuai indicator yang dibuat.Adapun hasil observasi dapat dilihat pada tabel berikut.

Tabel 1. Analisis hasil keaktifan siswa dalam pembelajaran

\begin{tabular}{|c|c|l|l|l|}
\hline Siklus & pertemuan & $\begin{array}{l}\text { Prosentase } \\
\text { keaktifan }\end{array}$ & $\begin{array}{l}\text { Rata- } \\
\text { rata }\end{array}$ & Kategori \\
\hline \multirow{2}{*}{ I } & 1 & $\begin{array}{l}50 \% \\
8 \text { siswa } \\
\text { aktif } \\
8 \text { siswa } \\
\text { pasif }\end{array}$ & 53,12 & Baik \\
\cline { 2 - 3 } & \multirow{2}{*}{2} & $\begin{array}{l}56,25 \% \\
\text { siswa } \\
\text { aktif } \\
7 \text { siswa } \\
\text { pasif }\end{array}$ & & \\
\hline
\end{tabular}

Hasil dari siklus 1 diketahui bahwa masih banyak siswa yang belum aktif Berdasarkan data diketahui bahwa keaktifan siswa meningkat dari $50 \%$ di pertemuan pertama menjadi $56,25 \%$ di pertemuan kedua,sehingga terjadi peningkatan $6,25 \%$, rata-rata keaktifan pada siklus ini $53,12 \%$,berada pada kategori baik.

2) Hasil Tes

Hasil tes pada siklus 1 dapat dilihat pada data berikut:

Tabel 2. Tabel prestasi belajar siswa pada siklus I

\begin{tabular}{|c|c|c|l|c|}
\hline N0 & Nilai & Frekwensi & \multicolumn{1}{|c|}{ Ketuntasan } & Persentase \\
\hline 1 & 70 & 9 & Tuntas & $56,25 \%$ \\
\hline 2 & 60 & 4 & Tidak tuntas tuntas & \multirow{2}{*}{$43,75 \%$} \\
\hline 3 & 50 & 1 & Tidak tuntas & \\
\hline 4 & 40 & 1 & Tidak tuntas & \\
\hline 5 & 20 & 1 & Tidak tuntas & \\
\cline { 1 - 2 } Rata-rata & 61,25 & & \\
\hline \multicolumn{2}{l|l}{ Nilai tertinggi } & 70 & & \\
\cline { 1 - 2 } Nilai terendah & 20 & & \\
\cline { 1 - 2 } $\begin{array}{l}\text { K e t u n t a s a n } \\
\text { Klasikal }\end{array}$ & 69 & & \\
\hline
\end{tabular}


Dari table diatas menunjukkan bahwa hasil tes siklus I belum mencapai kriteria yang diharapkan oleh peneliti,nilai rata rata 61,25 masih berada dibawah KKM sebesar 65, sedang ketuntasan klasikal $70 \%$,angka tersebut masih di bawah Ketuntasan klasikal yang diharapkan yaitu $75 \%$.Berdasar hasil pengamatan guru,banyak siswa yang belum tutas disebabkan kurangnya kemampuan menghitung angka.

d. Refleksi

Berdasar wawancara dengan beberapa siswa, mereka kurang aktif dikarenakan:

1) belum dapat menggunakan sumber belajar(buku paket) dengan baik,

2) kesulitan menyusun kata kata ketika mau bertanya

3) kurang percaya diri saat presentasi

4) lupa cara menggunakan alat

5) kemampuan menghitung kurang

Berdasarkan data diketahui bahwa keaktifan siswa baru mencapai $50 \%$, hal ini bisa dilihat dalam lembar observasi dimana dari 16 siswa hanya 8 yang mendapat kriteria aktif, oleh karena itu guru harus memberikan motivasi diawal pembelajaran bahwa salah satu nilai diambil dari keaktifan dalam pembelajaran. Guru harus memberikan pengertian tentang pentingnya membaca bagi seorang siswa,harus mau berlatih menyusun kalimat tanya serta berlatih percaya diri.Untuk ketrampilan menggunakan alat dan kemampuan menghitung guru menghimbau kepada siswa agar gemar berlatih.
Hasil belajar siswa yang tuntas mencapai $56,25 \%$,angka ini masih tergolong rendah dibandingkan kriteria yang ditetapkan yaitu $70 \%$,Oleh karena itu perlu dilakukan perbaikan pembelajaran pada siklus 2. Berdasar masukan dari observer selama proses PBM guru telah melaksanakan semua pembelajaran dengan baik,meskipun ada beberapa aspek yang belum sempurna, tetapi prosentase pelaksanaannya untuk masing masing aspek cukup, namun begitu atas saran observer guru harus memberikan perhatian lebih pada siswa terutama saat pelaksanaan eksperimen.

\section{Siklus 2}

Pelaksanaan kegiatan belajar mengajar siklus 2 dilaksanakan pada hari Rabu ,tanggal 7 Februari 2018 dan Kamis,8 Februari 2018 di kelas VIII dengan jumlah siswa 16.Dalam hal ini peneliti bertindak sebagai guru.Adapun proses belajar mengajar mengacu pada RPP yang telah dipersiapkan.Pengamatan (observasi) dilaksanakan bersamaan dengan proses belajar mengajar.

\section{a. Perencanaan}

Kegiatan yang dilakukan pada perencanaan siklus 2, hampir sama dengan perencanaan siklus 1 yang meliputi:menyusun Perangkat pembelajaran berupa RPP, membuat lembar kerja siswa , membuat lembar observasi,menyiapkan alat dan bahan percobaan serta catatan lapangan untuk mengumpulkan data tentang aktivitas siswa selama pembelajaran siklus 2 . 
b. Pelaksanaan

1) Pertemuan 1

Kegiatan diawali dengan berdoa bersama, setelah itu guru memotivasi siswa dengan bertanya" Megapa jarum yang sangat kecil ketika dimasukkan ke dalam air tenggelam, sedang kapal yang terbuat dari besi yang begitu besar bisa mengapung dalam air? Setelanhya guru menyampaikan tujuan pembelajaran,yaitu untuk mengetahui besarnya gaya ke atas dan faktor-faktor yang mempengaruhi bearnya gaya ke atas. Pada kegiatan ini siswa melakukan percobaan untuk mengetahui besarnya gaya keatas/gaya Archimides sesuai langkah kerja dalam LKS.Setelah selesai percobaan salah satu kelompok mempresentasikan hasilnya,sedang kelompok lain menanggapinya. Guru bersama-sama dengan siswa membuat kesimpulan,refleksi pembelajaran dengan menanyakan kesan terhadap pembelajaran yang telah diikuti.

Hasil dari pertemuan 1 siklus 2 ini kesiapan siswa untuk melakukan eksperimen sudah lebih baik dan antusias, hal ini dapat dilihat dari lembar observasi bahwa dari 5 kriteria keaktifan rata rata yang dilakukan sudah mencapai 3 point.Siswa sudah mulai menggunakan sumber belajar(buku paket ) tanpa harus diperintah,eksperimen berjalan lancar dan setelah selesai sebagian besar kelompok sudah bekerja secara mandiri,preseatasi kelihatan lebih komunikatif ,pertanyaan dari kelompok lain sudah mulai bermunculan,meskipun kalimat yang digunakan belum runtut.

2) Pertemuan 2

Pertemuan kedua siklus II dilaksanakan pada hari Kamis,tanggal 8 Februari 2018 jam 07.15 sampai dengan 09.20,sebanyak 3 jp dengan rincian 2jp pelaksanaan siklus dan 1 jam pelajaran tes siklus II.

Guru melakukan apresepsi dengan ,gelas diisi air sampai penuh kemudian ditutup dengan kertas dan dibalik maka air tidak akan tumpah,kemudian guru mengajukan pertanyaan mengapa hal itu bisa terjadi?

Siswa melakukan eksperimen sesuai langkah kerja dalam LKS. Guru mengakhiri pembelajaran dengan bersamasama menyusun kesimpulan,memberi pertanyaan secara lisan ,menanyakan kesan pembelajaran dan menginformasikan materi selanjutnya.

Hasil dari pertemuan ini keaktifan siswa sudah sesuai yang diharapkan ,siswa sudah kelihatan nyaman dengan metode eksperimen, hasil tes pada siklus ini sudah sesuai dengan kriteria yang ditetapkan.

c. Hasil pengamatan

1) Aktivitas belajar Siswa

Pada siklus kedua ini aspek yang diamati untuk mengethui aktivitas siswa, sama dengan siklus 1.Adapun hasil pengamatanya adalah sebgai berikut: 
Tabel 3. Analisis hasil keaktifan siswa dalam pembelajaran

\begin{tabular}{|c|c|c|c|l|}
\hline Siklus & pertemuan & $\begin{array}{c}\text { Prosentase } \\
\text { keaktifan }\end{array}$ & $\begin{array}{c}\text { Rata- } \\
\text { rata }\end{array}$ & Kategori \\
\hline \multirow{2}{*}{2} & 1 & $68,78 \%$ & \multirow{2}{*}{$71,89 \%$} & Baik \\
\cline { 2 - 3 } & 2 & $75 \%$ & & \\
\hline
\end{tabular}

Keaktifan siswa dalam pembelajaran pada siklus kedua meningkat dari pertemuan pertama $68,78 \%$ menjadi $75 \%$,terjadi peningkatan 7,2\%.Dibandingkan dengan hasil siklus pertama juga terjadi peningkatan sebesar $18,77 \%$.

\section{2) Hasil tes}

Hasil tes pada siklus 2 dapat dilihat pada data berikut:

Tabel 4. Tabel prestasi belajar siswa pada siklus 2

\begin{tabular}{|c|c|c|c|c|}
\hline N0 & Nilai & Frekwensi & Ketuntasan & Persentase \\
\hline 1 & 90 & 1 & Tuntas & \multirow{6}{*}{$75 \%$} \\
\hline 2 & 85 & & & \\
\hline 3 & 80 & 5 & Tuntas & \\
\hline 4 & 75 & 1 & Tuntas & \\
\hline 5 & 70 & 4 & Tuntas & \\
\hline 6 & 65 & 1 & Tuntas & \\
\hline 7 & 60 & 1 & Tidak tuntas & \multirow{6}{*}{$25 \%$} \\
\hline 8 & 55 & 1 & Tidak tuntas & \\
\hline 9 & 50 & & & \\
\hline 10 & 45 & 1 & Tidak tuntas & \\
\hline 11 & 40 & & & \\
\hline 12 & 35 & 1 & Tidak tuntas & \\
\hline \multicolumn{2}{|c|}{ Rata rata } & 69 & & \\
\hline \multicolumn{2}{|c|}{ Nilai tertinggi } & 90 & & \\
\hline \multicolumn{2}{|c|}{ Nilai terendah } & 35 & & \\
\hline \multicolumn{2}{|c|}{ Ketuntasan klasikal } & 75 & & \\
\hline
\end{tabular}

Dari tabel diatas menunjukkan bahwa hasil tes siklus 2 sudah mencapai kriteria yang diharapkan oleh peneliti,dimana nilai ketuntasan individu/rata-rata mencapai 69 sudah berada diatas kriteria yang ditetapkan 65 , sedang ketuntasan klasikal $75 \%$ juga sudah diatas kriteria yang ditetapkan yaitu $70 \%$.Berdasar hasil pengamatan guru bersama kolaborator,siswa sudah dapat menyesuaikan diri dengan metode yang disampaikan guru,dan dengan beberapa latihan di siklus sebelumnya maka kemampuan menghitung anak juga meningkat,hal ini dapat dilihat dari hasil tes untuk soal yang hitungan. d. Refleksi

Dari hasil refleksi diketahui bahwa: 
1) Aktivitas guru dan siswa dalam pembelajaran siklus I belum memuaskan, pada pembelajaran siklus II guru telah melaksanakan semua pembelajaran dengan baik sesuai RPP yang telah disusun dan siswa aktif selama proses pembelajaran .

2) Hasil evaluasi unjuk kerja kelompok (LKS) dan nilai tes formatif siklus I secara klasikal belum tuntas, karena siswa yang memperoleh nilai $\geq 60$ hanya sebesar $56,25 \%$ dibawah kriteria ketuntasan $65 \%$, namun pada siklus II baik secara kelompok (LKS) maupun individu, sudah mengalami peningkatan dan mencapai ketuntasan.

3) Keseluruhan hasil pembelajaran pada siklus I belum memuaskan dikarenakan siswa masih baru dengan penerapan metode eksperimen, hal ini berdasarkan hasil keaktifan siswa baru mencapai $53,12 \%$ di bawah $60 \%$.Namun pada siklus II siswa sangat senang dan antusias mengikuti kegiatan pembelajaran dengan penerapan metode eksperimen dengan hasil penghitungan keaktifan siswa mencapai $71,89 \%$ dengan kategori aktif.

Dari hasil penelitian ini menunjukkan bahwa penerapan metode eksperimen memiliki dampak positif dalam meningkatkan prestasi belajar siswa. Diketahui dari perolehan nilai hasil tes yang dikerjakan siswa baik secara individu maupun kelompok (LKS) mengalami peningkatan mulai dari kegiatan siklus I sampai siklus II dengan ketuntasan belajar hampir seluruh siswa.

Kemampuan guru dalam mengelola pembelajaran dengan penerapan metode eksperimen juga mengalami peningkatan, sehingga berakibat positif pada motivasi belajar siswa yang menjadi semakin aktif. Guru juga aktif memberikan bimbingan dan pengarahan dalam menyampaikan materii dan informasi kepada siswa selama proses pembelajaran. Respon siswa terhadap penerapan metode eksperimen pada pelajaran IPA juga sangat memuaskan.

Setelah melalui siklus 2, hasil belajar siswa mengalami peningkatan dibandingkan dengan siklus 1.Nilai terendah disiklus pertama 20 meningkat menjadi 35 disiklus kedua, sedang nilai tertinggi di siklus pertama 70 ,disiklus kedua mencapai 90.

Tabel:5 Perolehan Nilai,Rata-rata

kelas dan Ketuntasan klasikal

\begin{tabular}{|l|l|c|c|}
\hline N0 & \multicolumn{1}{|c|}{ Keterangan } & Siklus 1 & Siklus 2 \\
\hline 1 & Nilai terendah & 20 & 35 \\
\hline 2 & Nilai tertinggi & 70 & 90 \\
\hline 3 & Rata-rata kelas & 61,25 & 69 \\
\hline 4 & Ketuntasan klasikal & 56,25 & 75 \\
\hline
\end{tabular}

Dengan melihat perolehan nilai pada tiap tiap siklus ,maka peneliti merasa yakin dengan menggunakan metode eksperimen siswa lebih nyaman,senang, tidak merasa bosan sehingga nilai ketuntasan klasikal sudah melebihi KKM.

Hasil yang diperoleh dalam penelitian ini menguatkan penelitian sebelumnya yang dilaksanakan oleh Rini Susdamayanti dalam jurnal Pedagogia 
Vol 3 N0 2 Agustus 2014.

\section{KESIMPULAN}

Hasil penelitian menunjukkan pada siklus 1 diperoleh prosentase ketuntasan klasikal 56,25\% atau 9 siswa yang tuntas dari 16 siswa,ini dikatakan belum memenuhi standar indikator keberhasilan penelitian yaitu $70 \%$,sehingga tindakan penelitian dilanjutkan siklus 2.Pada siklus 2 terlihat peningkatan hasil belajar yang signifikan $75 \%$ atau 12 siswa tuntas(nilai $\geq 65$ ). Dengan demikian penggunaan metode eksperimen pada siswa kelas VIII SMP Muhammadiyah 2 Bambanglipuro memberikan peningkatan hasil belajar

\section{DAFTAR PUSTAKA}

Kodir Abdul,Popy Kamalia Devi.2017. Modul Pengembangan Keprofesian Berkelanjutan.Kementrian Pendidikan dan Kebudayan Direktorat jendral Guru dan Tenaga kependidikan.

R.Nuryani.2005.Strategi Belajar Mengajar Biologi,Malang.Universitas negeri Malang.

Sukidin, Basrowi \& Suranto. (2002). Manajemen penelitian tindakan kelas. ----: Insan Cendekia.

Arikunto Suharsimi, Suhardjono, Supardi. 2008. Penelitian Tindakan Kelas. Jakarta: PT Bumi Aksara

Parjono,Paidi,Sukamti.2007. Panduan penelitian Tindakan Kelas, Yogyakarta, UNY
Saiful Bahri Djamarah. 2002. Strategi Belajar Mengajar, Jakarta : PT Rineka Cipta

Yamin, Martinis. 2005. Strategi Pembelajaran Berbasis Kompetensi. Jakarta: Gaung Persada Press

Roestiyah. 2008. Strategi Belajar Mengajar. Jakarta: Rineka Cipta.

Assegaf Rachman.2008.Penelitian Tindakan Kelas. Yogyakata:Fakultas Tarbiah UIN Yogyakarta

Abdul majid.2015.Strategi pembelajaran.Bandung: PT Rosdakarya

Komaruddin Hidayat.2009. Active Learning. Yogyakarta.Insan Madani

Hendro Darmodjo \& Jenny R.E. Kaligis. (1992). Pendidikan IPA II.Jakarta: Departemen Pendidikan dan Kebudayaan.

Nurani Soyomukti. (2010). Teori-Teori Pendidikan. Jakarta: A-Ruzzmedia.

Syaiful Sagala. (2010). Konsep dan Makna Pembelajaran. Bandung: Alfabeta

Moedjiono dan M. Dimyati. (1992). Strategi Belajar Mengajar. Jakarta: Departemen Pendidikan Nasional Direktorat Jenderal Pendidikan Tinggi Direktorat Ketenagaan.

Susdamayanti Rini.2014.”Penerapan metode Eksperimen Untuk Meningkatkan Prestasi Belajar IPA Siswa kelas V SDN Bandung 3 Bangkalan."Jurnal Pedagogia. Vol. 3, N0 .2 